Ancient Tyranny 



\section{Ancient Tyranny}

Edited by Sian Lewis 
(C) in this edition Edinburgh University Press, 2006

(C) in the individual contributions is retained by the authors

\section{Edinburgh University Press Ltd}

22 George Square, Edinburgh

Typeset in 11/13 pt Sabon by Servis Filmsetting Ltd, Manchester, and printed and bound in Great Britain by Antony Rowe Ltd, Chippenham, Wilts

A CIP record for this book is available from the British Library

ISBN 0748621253 (hardback)

The right of the contributors to be identified as authors of this work has been asserted in accordance with the Copyright, Designs and Patents Act 1988. 